\section{DAMNIFICADOS DE LA RECONSTRUCCIÓN POST- TERREMOTO. EFECTOS DEL MODELO EN EL HÁBITAT RURAL DEL MAULE ${ }^{1}$}

Stefano Micheletti ${ }^{2}$ y Francisco Letelier Troncoso ${ }^{3}$

\section{VICTIMS OF POST- EARTHQUAKE RECONSTRUCTION. CONSEQUENCES ON THE RURAL HABITAT OF MAULE ${ }^{1}$}

\author{
Stefano Micheletti ${ }^{2}$, Francisco Letelier Troncoso ${ }^{3}$
}

\section{Abstract}

Following the earthquake and tsunami that occurred on February 27, 2010, the reconstruction policy implemented by the Chilean government favored a process led by private actors and offered standard urban-oriented solutions for all affected territories. Rural zones of the Maule Region, however, had to deal with weak local institutions and the lack of economic incentives for private agents to intervene in these highly disperse and thinly populated areas.

This paper reflects on the effects of reconstruction policies on the reality of rural communities and territories. The absence of policy frameworks 
implementada tuvo sobre la realidad de las comunidades y territorios rurales. Al no existir un marco de política pertinente con el hábitat rural, entendido no solamente como un conjunto de características físicas de un determinado espacio geográfico, sino como el resultado de procesos sociales, históricos e identitarios, los resultados dejan entrever que los programas de intervención pos-terremoto no reconocieron las particularidades del territorio. Esto significó el incremento de la precariedad en el habitar, la pérdida de patrimonio e identidad, y la profundización de los fenómenos de desplazamiento de la población hacia la periferia de las ciudades.

\section{PALABRAS CLAVE: TERREMOTO; RECONSTRUCCIÓN POST DESASTRE; HÁBITAT RURAL}

Recibido: 28-03-2015

Aceptado: 09-09-2015

1 Este trabajo es resultado de los procesos de intervención post terremoto desarrollados por ONG Surmaule entre el periodo 2010-2015 en la Región del Maule y de las iniciativas de investigación realizadas por los autores en el marco del Centro de Estudios Urbano-Territoriales de la Universidad Católica del Maule.

2 Chile. Presidente de ONG Surmaule e investigador asociado del Centro de Estudios Urbano-Territoriales de la Universidad Católica del Maule; titulado en Ciencias Forestales y Ambientales en la Universidad de Padua (Italia), diplomado en Gestión Pública y Desarrollo de los Territorios y con un Magíster Internacional en Cooperación para el Desarrollo. Correo electrónico: stefano. micheletti81@gmail.com.

3 Chile. Académico de la Universidad Católica del Maule y Director del Centro de Estudios Urbano-Territoriales; sociólogo de la Universidad de Concepción, Magíster en Sociología. Correo electrónico: fcoletelier@gmail.com. specifically designed to deal with the rural habitat, which should be understood as both a set of physical features and the result of social, historical and identity-related processes, suggests that post-earthquake programs failed to identify the particular characteristics of the territory. This increased the precariousness of living conditions, the loss of heritage and identity and the intensification of migration to peri-urban areas.

\section{KEYWORDS: EARTHQUAKE, POST-DISASTER RECONSTRUCTION, RURAL HABITAT}

Received: 28-03-2015

Accepted: 09-09-2015

1 This paper is the result of post-earthquake intervention processes developed by the NPO Surmaule over the 2010-2015 period in the Maule Region and the research initiatives conducted by the authors at the Center for Urban-Territorial Studies, Catholic University of Maule.

2 Chile. President at NPO Surmaule and associated researcher at the Center for Urban-Territorial Studies, Catholic University of Maule; graduated in Forestry and Environmental Sciences at the University of Padua (Italy); diploma in Public Management and Territorial Development; International MSc in Development Cooperation. Email: stefano.micheletti81@gmail.com.

3 Chile. Academic at the Catholic University of Maule; Director at the Center for Urban-Territorial Studies; Sociologist, University of Concepcion; MSc in Sociology. Email: fcoletelier@gmail.com. 


\section{Introducción}

A cinco años del terremoto y posterior tsunami del 27 de febrero de 2010, la constatación es que el sector rural, junto con ser el más afectado, fue a la vez el más invisibilizado en el proceso de reconstrucción. Las políticas adoptadas le entregaron el protagonismo a los actores del sector privado para la producción de soluciones habitacionales, determinando una radicalización de la perspectiva neoliberal, centralista, sectorial y urbana del proceso, y profundizando una tendencia que se venía experimentando en Chile desde hace décadas.

La elección de enfrentar de este modo una catástrofe extensa a nivel territorial y con una importante diversidad de daños y de afectados, terminó por profundizar la situación de precariedad de muchas familias que habitan (o habitaban) en territorios rurales: los damnificados del proceso de reconstrucción. Este fenómeno fue particularmente evidente en la Región del Maule, donde el impacto del sismo y posterior tsunami fue durísimo. Como lo sostienen Letelier y Boyco 4 , "76.581 viviendas quedaron dañadas -23.879 destruidas y 52.702 con daños mayores-, lo que corresponde al 21 por ciento del total de viviendas dañadas del país. De acuerdo a estimaciones oficiales, en el Maule existen alrededor de 65.000 familias

4 Letelier y Boyco, 2011, p. 28.

\section{Introduction}

Five years on since the earthquake and tsunami that occurred on February 27, 2010, it has been observed that the rural sector was the area most affected and ignored during the reconstruction process. The policies adopted put private actors on the center of the production of housing solutions, thus radicalizing the neoliberal, centralist, sectoral and urban nature of the process and intensifying a long-running tendency in Chile.

Choosing such an approach to address a nationwide catastrophe, which included different types of damage and victims, increased the precarious living conditions of those who live (or lived) in rural territories: the victims of the reconstruction process. This phenomenon was particularly evident in the Maule Region, which was severely hit by the earthquake and tsunami. According to Letelier and Boyco, "76,581 houses were damaged -23,879 destroyed and 52,702 considerably damaged-, which represents 21 percent of total damaged houses. Official figures say that there are approximately 65,000 affected families in Maule. According to the Ministry of Interior, 12 out of 28 critical communes are located in Maule".

$4 \quad$ Letelier and Boyco, 2011, p. 28. 
damnificadas. Según el Ministerio del Interior, de las 28 comunas críticas, 12 están en el Maule".

Dado el impacto del terremoto en la ruralidad de esta región, se precisa entender mejor las implicancias que las políticas de reconstrucción implementadas tuvieron en un territorio que tradicionalmente se ha mirado e intervenido desde la lógica urbana. En este sentido, una referencia interesante son las Directrices Operacionales del Comité Permanente entre Organismos (IASC), que representan un cuerpo de disposiciones muy relevante a la hora de abordar el tema del resguardo de los derechos humanos en contexto de desastre natural.

Las directrices tienen entre sus objetivos "garantizar que los principios de derechos humanos y normas de protección, incluyendo el principio fundamental de la no discriminación, sean integrados en todos los esfuerzos de respuesta y recuperación en casos de desastre desde la etapa más temprana posible" . Para este trabajo tiene especial relevancia el grupo de indicaciones relativo a la protección de los derechos relacionados con la vivienda y la tierra, que establecen temas centrales como a) los criterios de idoneidad que tienen que cumplir el alojamiento o vivienda temporal que se proporcione (accesibilidad, asequibilidad, habitabilidad, seguridad de tenencia, adecuación cultural, conveniencia de la ubicación, y acceso a ser-

$5 \quad$ IASC, 2011, p. 8.
Given the impact of the earthquake on the rural area of this region, there is a need to understand the effects of reconstruction policies on a territory that has been traditionally conceived from an urban perspective. In this sense, there is an interesting reference to the Operational Guidelines for the Inter-Agency Standing Committee (IASC), which are series of relevant regulations related to the protection of human rights during natural disasters.

One of the objectives of these guidelines is to "ensure that the principles of human rights and protection rules, including the fundamental principle of nondiscrimination, are integrated into all response and recovery efforts during the initial phases of disaster events". Some of these guidelines are important for the purposes of this paper, especially those related to housing and land rights that establish core topics such as a) suitability of temporary housing (accessibility, affordability, habitability, secure tenure, cultural adequacy, convenience of location and access to primary services such as health and education) and b) the right of all affected groups and people to be consulted, including their participation in the planning and implementation of temporary and permanent housing programs aimed at tenants and owners/occupants.

5 IASC, 2011, p. 8. 
vicios esenciales como salud y educación), y b) el derecho de todos los grupos y personas afectados a ser consultados, participando en la planificación y ejecución de los programas de alojamiento temporal y vivienda permanente, para inquilinos y propietarios/ocupantes.

Sin duda el IASC profundiza y especifica el concepto de derecho a la vivienda, que fue reconocido ya en el año 1948 con la Declaración Universal de los Derechos Humanos y que hoy la Organización de las Naciones Unidas contempla en más de 12 textos distintos. Este derecho no se reduce únicamente a la posibilidad de contar con un techo sino que abarca el acceso a un hogar y a una comunidad seguros para vivir en paz, con dignidad y salud física y mental ${ }^{6}$.

A partir de esta base, se analiza cómo las políticas de reconstrucción post terremoto profundizaron la vulnerabilidad de los sectores rurales del Maule (y de la zona central de Chile, más en general). Se asume el concepto de vulnerabilidad como lo define la Estrategia Internacional para la Reducción de los Desastres: "el conjunto de condiciones determinadas por factores o procesos físicos, sociales, económicos y ambientales, que aumentan la susceptibilidad de una comunidad al impacto de amenazas"7.

$6 \quad$ ¿Qué es derecho a la vivienda?, s.f.

7 Terminología (...), 2004.
There is no doubt that the IASC further explores and specifies the concept of the right to housing - recognized in the Universal Declaration of Human Rights of 1948 - which has been laid out in more than 12 different UN documents. Such a right does not only refer to the access to shelter but to the access to safe housing and a safe community that ensures peaceful and decent living conditions and physical and mental health ${ }^{6}$.

On the above basis, this paper analyzes how postearthquake reconstruction policies increased the vulnerability conditions of rural areas in the Maule Region (and central Chile). This research assumes the concept of vulnerability that has been defined by the International Strategy for Disaster Reduction as "a set of conditions determined by physical, social, economic or environmental factors or processes that increase the susceptibility of a community to the impact of hazards"'.

\section{Methodology}

Firstly, this paper analyzes different housing policies pursued within the rural context. In the second place, it proposes an analysis of the characteristics and relevance of different

\footnotetext{
6 ¿Qué es derecho a la vivienda?, no date.

7 Terminología (...), 2004
} 


\section{Metodología}

El artículo parte haciendo un análisis de las políticas de vivienda aplicadas en el contexto rural. En segundo lugar propone un análisis de las características y pertinencia de los distintos instrumentos de reconstrucción utilizados, al mismo tiempo que establece un conjunto de puntos críticos que a nivel cualitativo pueden ayudar a comprender las diferencias en el avance del proceso de reconstrucción en la ruralidad. En tercer lugar presenta un análisis comparado urbano-rural del impacto del terremoto y de los avances del proceso de reconstrucción, mostrando cómo a un nivel puramente cuantitativo existen diferencias importantes. Para poder realizar esta aproximación se identifican comunas "urbanas" y comunas "rurales", entendiéndose estas últimas como aquellas de hasta 20.000 habitantes ${ }^{8}$ y con un porcentaje de población rural superior al $12 \%{ }^{9}$. Según el criterio propuesto, se identificaron 18 comunas rurales en la Región del Maule.

Finalmente, y revisando documentos académicos, mapas, prensa y entrevistas a actores públicos y

8 Cuatro veces superior al mínimo oficial del INE de 5.000 habitantes, según la definición tomada por Berdegué de ciudad intermedia y según el Programa Human Settlements del International Institute of Environment and Development - IIED.

9 Valor límite de esta variable para la identificación de comunas urbanas según Berdegué, Jara, Modrego, Sanclemente y Schejtman, 2010. reconstruction instruments and establishes a series of critical points that, at a qualitative level, may be useful to understand the different progress rates within the rural reconstruction process. Thirdly, this research offers a comparative rural-urban analysis of the impact and progress made during the reconstruction process by showing critical quantitative differences. In order to achieve this, different "urban" and "rural" communes are identified, with the latter having a total population of up to 20,000 inhabitants ${ }^{8}$ and a rural population in excess of 12 percent ${ }^{9}$. According to the proposed criteria, 18 urban communes were identified in the Maule Region.

Finally, the analysis of academic literature, maps, press releases and interviews with experts and public actors makes it possible to identify the effects of the reconstruction process on the rural areas of Maule; this research concludes with some final thoughts on the issue.

8 This is four times the official number of inhabitants established by National Statistics Office, which is 5,000 , according to the definition of intermediate city described by Berdegue and the Human Settlement Program developed by the International Institute of Environment and Development - IIED.

9 Limit value for the identification of urban communes according to Berdegue, Jara, Moreno, Sanclemente and Schejtman, 2010. 
expertos, se identifican algunos efectos que el proceso de reconstrucción ha tenido en las zonas rurales del Maule, para terminar luego con algunas reflexiones finales.

\section{La ruralidad y las políticas públicas de vivienda}

En Chile, la tendencia general para la construcción de políticas de vivienda rural ha sido replicar los programas pensados para la ciudad, sin embargo, a partir de la década de los '70 se pueden apreciar esbozos de especificidad rural, como el programa habitacional de gobierno de $1972^{10}$. Dicho programa consideró la separación de la población de menores ingresos, para la producción de viviendas en dos grandes líneas: por un lado el núcleo urbano y por el otro la satisfacción de las necesidades del sector rural.

Posteriormente -en la década de los '80, en plena dictadura militar y en un intento por detener la migración a las ciudades- se generó el subsidio rural, lo que permitió la creación de los primeros villorrios rurales. También se creó el Programa de Mejoramiento de Barrios, que operando desde el Ministerio del Interior tenía como objetivo otorgar

10 Micheletti, 2011, p. 19.

\section{The Rural Space and Public Policies on Housing}

In Chile, the elaboration of policies on rural housing has been generally based on the replication of urban-oriented programs. However, the 1970s saw the emergence of the first attempts to create a rural specificity with the launching of the State housing program in $1972^{10}$. Such an initiative based the provision of housing for low-income families on two criteria: an urban core and the satisfaction of the needs of the rural sector.

Later on -during the 1980s, at the height of the military dictatorship and as an attempt to halt migration to cities - the creation of the Rural Subsidy enabled the emergence of the first rural villages. Likewise, the Neighborhood Improvement Program was created under the Ministry of Interior in order to provide basic sanitary solutions for low-income families who lived in poor hygiene conditions. These solutions were not to cost more than $110 U \mathrm{UF}^{11}$ and the area intended for the construction of kitchens and bathrooms ranged from 6 to 12 square meters.

\footnotetext{
10 Micheletti, 2011, p. 19.

11 The UF (Unidad de Fomento) is a unit of account that is adjusted according to inflation rates. Such a unit has been used in Chile since 1967 and is currently valued at 25,000 CLP, about 42 USD.
} 
soluciones de infraestructura de saneamiento básico a familias de escasos recursos y en condiciones de marginalidad sanitaria. Las soluciones entregadas debían tener un costo máximo de 110 Unidades de Fomento ${ }^{11}$ (UF) y una superficie desde 6 $\mathrm{m}^{2}$ hasta $12 \mathrm{~m}^{2}$, para la construcción de la zona húmeda (baño y cocina).

Ya en la década de los '90 aparecieron el Fondo Solidario de Vivienda, que otorgaba un subsidio de 280 UF, y el Programa de Vivienda Progresiva, que también tuvo algún impacto en el sector rural. Este último, a través de la erradicación de asentamientos precarios urbanos y rurales, respondió al déficit cuantitativo de viviendas en el país y logró alcanzar una población objetivo que no estaba siendo cubierta por los programas existentes a la fecha, sin embargo, produjo una fuerte urbanización del campo ${ }^{12}$. Con el tiempo, el Programa de Vivienda Progresiva evolucionó hacia una orientación que permitía incorporar al sector privado en su implementación, a través de los fondos concursables para proyectos habitacionales solidarios, que consistían en el desarrollo de las segundas etapas de las viviendas progresivas. El resultado de esta modificación tuvo un menor desarrollo

11 La Unidad de Fomento (UF) es una unidad de cuenta reajustable de acuerdo con la inflación, usada en Chile a partir del año 1967; actualmente su valor es de 25.000 CLP aproximadamente, 42 US\$.

12 Morellato, 2012, p. 29.
The 1990s saw the creation of the Housing Solidarity Fund, which granted housing subsidies equivalent to $280 \mathrm{UF}$ and the Progressive Housing Program, which had some impact on the rural sector. The latter initiative, which aimed at eradicating precarious urban and rural settlements, succeeded in both providing a solution to a quantitative housing deficit and reaching a target population that was not covered by the then-welfare programs. This plan, however, generated an important urbanization process in rural areas ${ }^{12}$. Over time, the Progressive Housing Program incorporated private actors through the Grant Funds for Solidarity Housing Projects, which consisted in the construction of new progressive housing units in areas that were already developed. Such a modification resulted in a reduced quantitative development due to the difficulty of working on inhabited areas.

Finally, the creation of the Chile Barrio Program in 1996 led to the greatest gains in construction and urban terms. This is because the mechanisms and tools implemented by this initiative did not only focus on the provision of a "shelter and four

12 Morellato, 2012, p. 29. 
cuantitativo que las primeras etapas, debido a la alta complejidad de construir en lotes habitados.

Finalmente, es la aparición en el año 1996 del Programa Chile Barrio el que desde el punto de vista constructivo y de urbanización logra la mayor satisfacción. Esto se explica porque los mecanismos y herramientas empleadas no se limitaban a otorgar una solución habitacional proveyendo a las familias de "un techo y cuatro paredes", sino que consideraban la gestión de medios para mejorar significativamente las condiciones de vida de las familias en diferentes ámbitos (desarrollo comunitario e inserción social, habilitación laboral y productiva, etc. $)^{13}$.

Las políticas habitacionales fueron aplicadas en la ruralidad sin mucho control (tanto desde el Estado como de las comunidades), ni previsión de resultados de su impacto a mediano y largo plazo. La desinformación de los habitantes rurales acerca de estas políticas puede observarse también hoy día, así como la poca fiscalización en términos de calidad de construcción, lo cual genera muchas insatisfacciones en las soluciones recibidas. La escasa participación de las comunidades en el diseño e implementación de las políticas termina en algunos casos favoreciendo la generación de subsidios indirectos desde el Estado a la empresa privada.

13 MINURVI, 2006, p. 1. walls" but on the management of means designed to significantly improve the living conditions of families in different areas (community development, social inclusion, job and skills training, etc. $)^{13}$

The above housing policies were implemented in the countryside without much control (neither by the State or communities) and there was no awareness of the medium or long term consequences of these initiatives. Misinformation on the part of rural inhabitants about these policies and little inspection of quality can be seen even today, which generates high levels of dissatisfaction about housing solutions. In some cases, the lack of community involvement in the design and implementation of these policies favor the generation of indirect subsidies from the State to private building firms.

At the local level this situation generates some problems for rural municipalities that have no control over the emergence of a considerable number of semi-urban villages and the abnormal growth of their outlying areas. Such an issue is related to the endemic lack of resources and technical capacities, especially in the case of small, rural and isolated municipalities. This being the case, "large rural areas are engaged

13 MINURVI, 2006, p. 1. 
A nivel local se crean problemas para los municipios rurales que no tienen control sobre el surgimiento de innumerables villorrios semi urbanos y el crecimiento inorgánico de las periferias de los centros poblados de las comunas rurales. Esto tiene relación con la falta endémica de recursos y capacidades técnicas que padecen sobre todo las municipalidades más pequeñas, más rurales y más aisladas. Así las cosas, "extensas áreas rurales se están autoplanificando, reproduciendo y traspasando la continuidad de las inequidades urbanas al medio rural, reproduciendo en su base las deficiencias de las cuales nos horrorizamos al ver ciudades contaminadas, caras y con un alto costo de corrección"14.

Evidentemente la ruralidad esconde una condición muy heterogénea y en este sentido "la política habitacional (...) no distingue en su aplicación un tratamiento diferenciado para nuestro peculiar y heterogéneo territorio. Dado que es el sector privado quien realiza las funciones más estratégicas del proceso habitacional (entre ellas, la gestión del suelo) en gobiernos locales insuficientemente preparados para responder las interrogantes del problema, la dimensión cultural, componente de la calidad residencial, es una ausente en las políticas"15.

14 Tapia, 2006, p. 1.

15 Ibíd. in self-planning initiatives, reproducing and transferring the continuity of urban inequalities to the rural sphere, thus replicating the problems that fill us with horror when we see polluted and expensive cities with high correction costs"14.

It is clear that there is some heterogeneity underlying the rural sphere, in this sense "housing policies (...) do not provide a special treatment to our peculiar and heterogeneous territory. This is because the private sector carries out the most strategic functions (such as land management) of the housing process in inadequately prepared local governments. The cultural dimension, which is an element of residential quality, is therefore excluded from these policies" ${ }^{\prime 15}$.

The reconstruction process reproduced and intensified the abovementioned weaknesses and failed to include the lessons learned from other experiences. In fact, as Letelier and Boyco ${ }^{16}$ suggest, the neoliberal model "has not always influenced Chilean reconstruction processes nor has it defined other contemporary cases. In past decades the Chilean State was able to turn reconstruction processes into real opportunities". It was only after the 1985 earthquake that the

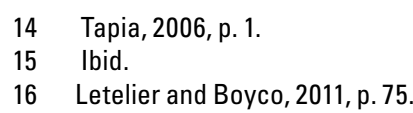
of Maule/Stefano Micheletti, Francisco Letelier Troncoso 
El proceso de reconstrucción reprodujo y acrecentó las mismas debilidades antes señaladas, y no fue capaz de incluir los aprendizajes derivados de otras experiencias que se han tenido en Chile; de hecho, tal como lo sostienen Letelier y Boyco ${ }^{16}$, el modelo de corte neoliberal "no siempre ha marcado los procesos de reconstrucción en Chile, ni es la regla en otros casos contemporáneos. En décadas pasadas, el Estado chileno fue capaz de hacer de los procesos de reconstrucción verdaderas oportunidades". Fue solamente luego del terremoto de 1985 que el Estado pasó a tener un rol más bien subsidiario, lo que complicó especialmente a los territorios rurales.

\section{Marco general de política e instrumentos disponibles para la reconstrucción de vivienda en los territorios rurales}

El proceso de reconstrucción pos terremoto en Chile presentó algunos ámbitos críticos que han sido foco de cuestionamientos permanentes por parte de los damnificados ${ }^{17}$ y de las autoridades lo-

16 Letelier y Boyco, 2011, p. 75.

17 Cabe destacan la actoría que ha tenido el MNRJ (Movimiento Nacional por la Reconstrucción Justa) a nivel nacional, apoyado por organizaciones como el Observatorio de Reconstrucción de la Universidad de Chile y ONG Surmaule, entre otras.
State assumed a subsidiary role; such a measure primarily affected rural territories.

\section{General Policy Framework and Available Instruments for Housing Reconstruction in Rural Territories}

The Chilean post-earthquake reconstruction process has shown some critical aspects that have been constantly criticized by both victims ${ }^{17}$ and local authorities. According to Bresciani ${ }^{18}$ these social conflicts are the result of the lack of clear citizen participation initiatives, a strong and centralized control over the reconstruction process and the lack of political agreement. Some of these critical aspects are listed as follows:

- There has not been an institutional framework intended exclusively to address this issue as in the case of the successful post-earthquake experience of Armenia, Colombia or past experiences in Chile.

17 It is worth mentioning the role played by the NMFR - National Movement for Fair Reconstruction - at national level. This initiative has been supported by organizations such as the Reconstruction Observatory of the University of Chile and the NPO Surmaule, among others.

18 La reconstrucción reprobada (...), 2011 
cales. Según Bresciani ${ }^{18}$, los conflictos sociales que se han generado se deben a la inexistencia de procedimientos explícitos de participación ciudadana, al fuerte control centralizado del proceso de reconstrucción y a la escasa voluntad de convergencia política entre los distintos sectores. Entre los ámbitos críticos podemos mencionar los siguientes:

- No ha existido una institucionalidad con la función de trabajar y liderar en forma exclusiva el tema, como ha pasado en otras exitosas experiencias pos-terremoto, por ejemplo en el caso de Armenia, en Colombia, pero también en terremotos anteriores en Chile.

- Se utilizaron los mecanismos y programas regulares (por ejemplo el Fondo Solidario de Vivienda I y II y el Decreto Supremo 40) pese a la excepcionalidad de la situación.

- Para la asignación de subsidios se ha actuado con una lógica según la cual es natural considerar la selección de los damnificados en función de su situación socio-económica, en claro contraste con el derecho internacional y las indicaciones de la ONU en materia de vivienda adecuada.

- Las cifras de avance en reconstrucción entregadas por el gobierno han sido blanco de críticas constantes, debido al tratamiento poco transparente de los datos. Se puede afirmar

18 La reconstrucción reprobada (...), 2011.
- Regular programs and mechanisms (such as the Housing Solidarity Fund I and II and the Supreme Decree No. 40) were used despite the exceptional nature of the situation.

- The allocation of subsidies has been based on the selection of victims according to their socio-economic situation, which is in sharp contrast to the provisions of international law and the UN in terms of adequate housing.

- Reconstruction figures provided by the Government have been constantly criticized due to a lack of transparency in data management processes. It is possible to say that different sectors have identified a crisis associated with the gap between political initiatives and the effective production of results ${ }^{19}$.

- Reconstruction programs have adopted a neoliberal approach, favoring the emergence of a real estate market focused on the replacement of dwellings rather than on the provision of quality solutions for victims and their neighborhoods. In this context neither the market nor the reconstruction process are controlled by the State, which has adopted a subsidiary role.

19 Valenzuela, 2011, p. 32 
que hace tiempo se instaló transversalmente la constatación de una crisis alojada en la brecha entre los discursos y designios políticos y la producción efectiva de resultados ${ }^{19}$.

- Los programas de reconstrucción han operado desde una lógica neoliberal, privilegiando la conformación de un mercado inmobiliario vinculado a la reposición de viviendas y no a la entrega de soluciones de calidad para los damnificados, sus barrios y pueblos. El Estado termina desenvolviendo entonces un papel meramente subsidiario, dejando operar al mercado y sin asumir un rol central en el proceso de reconstrucción.

Los ámbitos críticos se ven agudizados en las zonas rurales por tres factores: las características sociales y territoriales específicas de la ruralidad, las características de las políticas de vivienda históricamente vinculadas a este medio, y las características del modelo de reconstrucción, centrado en el protagonismo del mercado y en el rol reducido del Estado. Para analizar con más atención la temática rural, es preciso abordar ahora el análisis de los instrumentos públicos disponibles y su aplicación en el territorio.

19 Valenzuela, 2011, p. 32.
In rural areas these critical aspects are intensified by three factors: the social and territorial features common to rural zones; the characteristics of housing policies that have been historically associated with these areas; and the characteristics of the reconstruction model that favor the market and reduce the presence of the State. Before further analyzing this rural issue, it is necessary to address the study of available public instruments and their implementation in the territory.

The post-earthquake reconstruction phase began right after the ending of the emergency phase. ${ }^{20}$ The entity in charge of this undertaking was the Ministry of Housing and Urban Development and the objective was to provide housing solutions for victims and reconstruct their cities, towns and stevedores, maintain the allocation of subsidies and give continuity to the then-ongoing subsidy programs $^{21}$. In practice, this model was based on the use of available subsidies to concentrate and allow resources. Some of the identified funding mechanisms were related to the provision of extra resources, contributions made by the private sector and other sources, and budgetary reallocation.

20 This phase was led by the Ministry of Interior and MIDEPLAN, along with municipalities and public and private organizations. The objective of this stage was to provide provisory shelter for affected families.

21 Ministerio de Vivienda y Urbanismo, 2010, p. 5. 
Luego de enfrentarse la primera etapa de emergencia $^{20}$, la recuperación pos-terremoto entró en la fase de reconstrucción. El organismo responsable del proceso fue el Ministerio de Vivienda y Urbanismo en el ámbito de vivienda, cuyos objetivos se centraron en entregar solución definitiva a las familias damnificadas y reconstruir ciudades, pueblos y caletas, manteniendo a la vez todos los subsidios previamente asignados, así como la continuidad de los programas habituales de subsidio ${ }^{21}$. En la práctica, el modelo operó con el uso del mecanismo de subsidios existentes como herramienta para focalizar y asignar los recursos. Entre los mecanismos de financiamiento que se identificaron figuraron recursos extraordinarios, aportes del sector privado y otras fuentes, así como reasignación presupuestaria.

En este contexto, se trató en un primer momento de dar solución a las problemáticas de reconstrucción a través de los programas habitacionales del ministerio, siendo básicamente tres:

- Fondo Solidario de Viviendas, que asigna subsidios de 330 a 580 UF para comprar o construir viviendas, sin crédito hipotecario, en sus tipologías: adquisición de vivienda construida, construcción en sitio propio, construcción en nuevos terrenos y construcción colectiva en zonas rurales.

20 En esta etapa, los organismos responsables fueron el Ministerio del Interior y MIDEPLAN, en conjunto con municipios y organismos públicos y privados, y el objetivo fue entregar un techo provisorio para familias damnificadas.

21 Ministerio de Vivienda y Urbanismo, 2010, p. 5.
In this context, there was an attempt to solve reconstruction issues through three Ministerial housing programs:

- The Housing Solidarity Fund, which allocates subsidies ranging from 330 to 580 UF to purchase or build dwellings without the need to have a mortgage account; such a benefit considered the following typologies: the purchase of new dwellings, self-help construction in areas that belong to the beneficiary, construction in new lands and collective construction in rural areas.

- The Housing Subsidy for Middle-Income Groups (Supreme Decree No.40), which allocates subsidies ranging from 200 to 300 UF to build or purchase new or used dwellings in urban or rural zones with optional mortgage funding.

- The Program on the Protection of Family Heritage, which was intended to provide resources for the restoration of dwellings through the funding of habitability, safety and maintenance measures. Subsidies ranged from 50 to $65 \mathrm{UF}$. 
- Subsidio Habitacional para los Sectores Medios (Decreto Supremo 40), que asigna subsidios de 200 a 300 UF para sectores medios, para construir o comprar viviendas nuevas o usadas, en zonas urbanas y rurales, y con crédito hipotecario opcional.

- Programa de Protección del Patrimonio Familiar, para la reparación de viviendas, financiando proyectos de habitabilidad, seguridad y mantención con subsidio de 50 a 65 UF.

Sin embargo, las dificultades encontradas durante el proceso, sobre todo en cuanto a la lentitud de la reposición de viviendas, obligó al gobierno a incorporar nuevas medidas, modificando los decretos de ley que normaban la aplicación de los programas. En enero de 2011, el Ministerio de Vivienda y Urbanismo publicó una propuesta de ajuste a la política habitacional, justificada por los "problemas de focalización que tienen los actuales instrumentos, lo que desvía los recursos de aquellas familias que realmente lo necesitan", y asumiendo que "el actual mecanismo de calificación y selección de los proyectos ha permitido el desarrollo de un número considerable de conjuntos de muy mala calidad en términos técnicos y urbanísticos"22. La Nueva Política Habitacional consideró entonces el estreno del Decreto Supremo No 1 de 2011 y del Decreto Supremo $N^{\circ} 49$ de 2011, en reemplazo de los programas

22 Ministerio de Vivienda y Urbanismo, 2011.
However, difficulties encountered during the process, especially those related to the slow replacement of dwellings, prompted the government to incorporate new measures and modify the decree-laws that defined the implementation of the above programs. On January, 2011, the Ministry of Housing and Urban Development issued a proposal for adjustment of housing policies due to the "targeting problems of current instruments, which divert resources away from families who really need to be assisted", assuming that "the current mechanism for the qualification and selection of projects has enabled the development of a considerable number of low-quality developments"22. This New Housing Policy, which was based on the then new Supreme Decree No. 1 of 2011 and the Supreme Decree No. 49 of 2011, replaced the abovementioned programs in order to improve the targeting of resources, thus simplifying and enhancing the array of possibilities for the allocation of subsidies.

Likewise, three different measures were added to the already existent initiatives related to the allocation of subsidies in rural areas:

1 The Assisted Self-Help Construction, which, through technical assistance provided by the Housing and Urban Development Service, enabled families who owned a plot of land to

22 Ministerio de Vivienda y Urbanismo, 2011. 
anteriores, con el objetivo de mejorar la focalización de los recursos, simplificando y ampliando la gama de posibilidades de aplicación de los subsidios.

A su vez, se propusieron tres medidas especiales relevantes para la ruralidad, que se sumaron a las ya existentes en cuanto a la modalidad de aplicación de los subsidios:

1) la Autoconstrucción Asistida, que permitió a las familias propietarias de un sitio autoconstruir una vivienda, con una asesoría técnica asignada por el Servicio de Vivienda y Urbanización; el subsidio entregado fue de 380 UF (300 UF para materiales y 80 UF para mano de obra), más la asistencia técnica, que se contrataba por un monto de 60 UF;

2) el Subsidio Portable, que permitió a personas damnificadas recibir apoyo para financiar la construcción de una vivienda en su sitio, o bien para financiar la compra de una vivienda nueva en el mercado inmobiliario; el subsidio fue de 100 a 350 UF, dependiendo del precio de la vivienda, que podía llegar hasta $2.000 \mathrm{UF}$;

3) el Ministerio de Bienes Nacionales comenzó a profundizar la acción del Programa de Regularización Express de los títulos de dominio.

Los diferentes programas tuvieron resultados diversos en los sectores rurales: En la tabla 1 se analiza cada uno de ellos. build their dwellings; beneficiaries received a subsidy of 380 UF (300 UF for materials and 80 UF for manpower) and technical assistance equivalent to $60 \mathrm{UF}$;

2 The Portable Subsidy, which supported victims through the allocation of subsidies to fund the replacement of damaged dwellings or fund the purchase of a new dwelling; beneficiaries received a subsidy ranging from 100 to 350 UF depending on the price of the new housing units, which could not cost more than 2000 UF;

3 The Ministry of National Assets deepened the implementation of the Express Regularization Program intended to regularize legal tenure documents.

These initiatives had mixed results in rural areas (table 1). 
TABLA 1. ANÁLISIS DE LAS MODALIDADES DE REPARACIÓN Y RECONSTRUCCIÓN PARA SECTORES RURALES.

\section{Modalidad \\ Destinatarios \\ Análisis}

Auto-Reparación Banco Damnificado sujeto de subsidio de Materiales con daños reparables en la

\begin{tabular}{ll}
$\begin{array}{l}\text { Reparación a través de } \\
\text { PSAT }^{23} \text { o EGIS }\end{array}$ & $\begin{array}{l}\text { Damnificado sujeto de subsidio, } \\
\text { con daños reparables en la } \\
\text { vivienda. }\end{array}$ \\
\hline $\begin{array}{l}\text { Subsidio de Construcción } \\
\text { en Sitio Propio }\end{array}$ & $\begin{array}{l}\text { Familias propietarias de las } \\
\text { viviendas que hayan resultado } \\
\text { inhabitables. }\end{array}$
\end{tabular}

Subsidio para Construc- $\quad$ Familias propietarias de las ción con Vivienda Tipo viviendas que hayan resultad

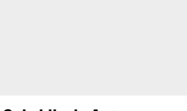

Subsidio de Autocons trucción Asistida

Subsidio de Adquisició de Vivienda Construida

Subsidios de Construcción en Nuevos Terrenos viviendas que
inhabitables.

Medida extraordinaria introducida en 2011 para damnificados con terreno; solución fundaruralidad.

Medida extraordinaria introducida en 2011 para damnificados con terreno.

Familia damnificada no propietaria con daño irreparable.

Familia damnificada no propietaria con daño irreparable.
El subsidio pretendió financiar la reparación de viviendas dañadas, considerando los materiales necesarios y la asistencia y supervisión técnica de un prestador de servicios de asistencia técnica designado por el Servicio de Vivienda y Urbanización, quien velaría por la correcta ejecución de las obras. No era necesario contar con ahorro previo para postular a este subsidio.

Los beneficiarios recibieron una tarjeta para comprar materiales y herramientas para las reparaciones, en ferreterías y otros establecimientos del rubro autorizados por el Ministerio de Vivienda y Urbanismo. Esto generó dificultades para la búsqueda de mejores precios, considerando sobre todo que las adquisiciones se autorizaron solamente en algunas cadenas de venta. Para las zonas rurales, además, se generaron complicaciones debido a la necesidad de transportar los materiales, lo que encareció la obra.

Por otro lado, el monto de $62 \mathrm{UF}$ entregado fue bastante bajo, pensando en la necesidad de efectuar reparaciones en fundaciones, muros, tabiques, cielos,

También en este caso, el subsidio pretendió financiar la reparación de viviendas dañadas por el sismo, entregando un monto entre 55 y 65 UF (dependiendo de la comuna) para efectuar reparaciones en fundaciones, muros, tabiques, cielos, techumbres, etc., lo que representó en general un aporte bajo para daños de la comuna) para efectuar reparaciones en fundacior
envergadura como los que produjo el terremoto.

Por otro lado, los subsidios de más alto valor estaban destinado a zonas extremas, donde no ocurrió el terremoto, por lo tanto terminó siendo un subsidio que no consideró la localización aisladas, de las viviendas rurales, ni el nivel de daño sufrido. Además de la reconstrucción de la vivienda, estos subsidios cubrieron los gastos necesarios para demolición y extracción de escombros, (rehabilitar u sentó dificula dispersos. Como conecuenci, en muchos casos las faenas no emperaron nunca o se abandonaron cuando ya estaban en obra

La construcción con vivienda tipo permitió reducir bastante los tiempos de ejecución, sin embargo la materialidad de las viviendas que se construyeron La construcción con vivienda tipo permitió reducir bastante los tiempos de ejecución, sin embargo la materialidad de las viviendas que se construyeron

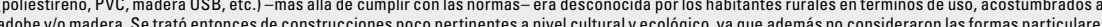
de habitar y producir que caracterizan lo rural.

Por otro lado, el traslado a sectores rurales encareció bastante los costos y muchas veces las empresas privadas no tuvieron interés en llevar pocos módulos. Además, para poder construir con este subsidio, el modelo de vivienda tipo tenía que estar certificado por las empresas constructoras con el Servicio de Vivienda y Urbanización o la División Técnica de Estudios del Ministerio de Vivienda y Urbanismo.

Subsidio de 380 UF para autoconstruir una vivienda en un sitio de propiedad del beneficiario, con asesoría técnica asignada por el Servicio de Vivienda y Urbanización. Permite comprar materiales de construcción en centros ferreteros autorizados por el Ministerio de Vivienda y Urbanismo, con una tarjeta Urbanización. Permite comprar materiales de construcción en centros ferreteros
nombre del beneficiario. No se requiere contar con ahorro previo para postular.

Permite generar soluciones donde es más difícil llegar con empresas constructoras y permite soluciones en terrenos que no estén 100\% regularizados. Esta modalidad representa un paso hacia adelante en la valorización de la mano de obra de los mismos damnific ados, aunque la vivienda a construir se restringe a modelos predefinidos, presentando algunos problemas de pertinencia ecológica y cultural.

A través de esta medida, es posible utilizar el monto del subsidio para construir en sitio propio o bien para comprar una vivienda en otro terreno. Considerando que la oferta inmobiliaria de viviendas para damnificados se ha concentrado en las zonas periféricas de los sectores urbanos, se puede pensar en línea teórica que esta medida profundiza el flujo migratorio desde el campo a la ciudad.

Como en el caso anterior, no existiendo oferta inmobiliaria en los sectores rurales, la gente que opta por este subsidio se ve obligada a emigrar a los sectore periféricos de los pueblos y ciudades intermedias, donde se están construyendo viviendas de bajos estándares habitacional y urbano.

Este subsidio es para financiar la compra del terreno y para su habilitación (relleno para nivelar, muros de contención, plantas elevadoras sanitarias, etc.), pensando en la construcción de proyectos colectivos de viviendas en nuevos terrenos. En los sectores rurales, la aplicación de esta modalidad es bastante compleja, debido esencialmente a la dificultad de reunir el número de personas necesarias para hacer viable el proyecto, a la falta de terrenos urbanizados o al costo elevado para urbanizarlos.

Elaboración propia y datos del MINVU25

23 Ministerio de Vivienda y Urbanismo, 2010.

24 Prestador de Servicios de Asistencia Técnica.

25 Entidad de Gestión Inmobiliaria Social.

ARTíCULO: Damnificados de la reconstrucción post-terremoto. Efectos del modelo en el 


\section{TABLE 1. ANALYSIS OF REHABILITATION AND RECONSTRUCTION MEASURES IN RURAL AREAS.}

\section{Measure}

\section{Beneficiaries}

Self-help rehabilitation Provision of materials damage
Victims whose dwellings received repairable

\begin{tabular}{ll}
$\begin{array}{l}\text { Rehabilitation through PTA } \\
\text { or ASREM }\end{array}$ & $\begin{array}{l}\text { Victims whose dwellings received repairable } \\
\text { damage }\end{array}$ \\
$\begin{array}{l}\text { Subsidy for construction } \\
\text { in lands owned by their in- } \\
\text { habitants }\end{array}$ & $\begin{array}{l}\text { Families owning dwellings declared as unsuit- } \\
\text { able for habitation }\end{array}$ \\
\hline $\begin{array}{l}\text { Subsidy for construction of } \\
\text { prefabricated dwellings }\end{array}$ & $\begin{array}{l}\text { Families owning dwellings declared as unsuit- } \\
\text { able for habitation }\end{array}$ \\
\hline $\begin{array}{l}\text { Subsidy for assisted self- } \\
\text { help construction }\end{array}$ & $\begin{array}{l}\text { Extraordinary measure implemented in } 2011 \text { in } \\
\text { order to support victims that owned plots of } \\
\text { land: this solution was aimed at rural sectors }\end{array}$
\end{tabular}

Portable subsidy

\section{Subsidy for the purchase of} dwellings

Subsidy for construction in Subsides of land

Tenant families whose dwelling was declare as damaged beyond repai

\section{Analysis}

This subsidy aimed at funding the rehabilitation of damaged dwellings by providing the materials and the technical assistance and supervision of a Provider of Technical Assistance appointed by the Housing and Urban Development Service, which was the entity in charge of overseeing the proper implementation of tasks. Beneficiaries were not required to have a savings account.

Beneficiaries received a card to purchase materials and tools in hardware stores authorized by the Ministry of Housing and Urban Development. This generated difficulties to find better prices since only a small number of retail chains were authorized to sell these products. There were some problems in rural areas due to the need to transport purchased materials; this was a fact that increased the overall cost of the project.

On the other hand the benefit provided by authorities (62UF) was not enough to cover the damage to foundations, walls, partitions, ceilings, roofs after a magnitude 8.8 earthquake.

In this case the benefit was intended to fund the rehabilitation of damaged dwellings by granting a subsidy of 55 - 65 UF /depending on the affected commune) for the repair of foundations, walls, partitions, ceilings, roofs, etc. This benefit was not enough considering the damage caused by the earthquake.

On the other hand the highest subsidies were distributed in remote areas that were not affected by the earthquake. Such a benefit did not consider the isolated location of rural dwellings or the damage suffered by structures.

Apart from the reconstruction of dwellings, these subsidies covered demolition and debris removal expenses, the rehabilitation of basic services and soil improvement and retaining works. In the case of rural areas, this reconstruction measure had some problems associated with the lack of interest on the part of the SREA and real estate firms to build developments in isolated and dispersed territories. As a result some projects never materialized or were abandoned while still in progress.

The building of prefabricated dwellings considerably reduced construction timelines. However, while complying with quality standards, the materials used to build these housing units (polystyrene, PVC, sterling board, etc.) were unfamiliar to rural people as they were used to live in wooden or adobe dwellings. Therefore, these units lacked cultural and ecologic relevance since they did not consider the particular living and production costumes common to rural areas.

On the other hand, the transport of materials to rural sectors increased the cost of projects and, on many occasions, private contractors had no interest in transporting little amount of modules to these areas. Likewise, these prefabricated dwellings should be authorized by the Housing and Urban Development Service or the Technical Division at the Ministry of Housing and Urban Development.

This benefit granted a subsidy of 380 UF for individuals who wanted to build a dwelling in their own plots of land; this benefit also included technica assistance provided by the Housing and Urban Development Service. Beneficiaries were given a card to purchase construction materials in hard-

This subsidy generated solutions for remote areas that were difficult to access for building firms and provided solutions in unregulated lands. This measure constitutes a step forward in relation to the valuation of the work carried out by victims despite the fact that these are prefabricated dwellings that lack cultural and ecologic relevance.

Extraordinary measure implemented in 2011 This benefit can be used either to build a new dwelling in the area owned by victims or purchase a new dwelling in other place. Considering that the in order to support victims that owned plots real estate market for victims is focused on peri-urban areas it is possible to say, then, that this measure increases rural-urban migration.

As in the previous case, since the real estate market is exclusively focused on urban zones, recipients of this benefit are forced to migrate to the peri-urban areas of towns and intermediate cities and live in dwellings with low housing and urban standards.

This subsidy focuses on the construction of collective housing projects in new sites and is intended to fund the purchase of land and its furthe highly complex due to the lack of enough people to start the project, the lack of developed londs and high construction costs.

Elaborated by the authors according to data retrieved from MINVU25

23 Provider of Technical Assistance (in Spanish Prestador de Servicios de Asistencia Técnica)

24 Agency for Social Real Estate Management (in Spanish Entidad de Gestión Inmobiliaria Social).

25 Ministerio de Vivienda y Urbanismo, 2010.

34 revista invi № 86 / Mayo 2016 / Volumen $N^{0}$ 31: 17-58

ARTICLE: Victims of post-earthquake reconstruction. Consequences on the rural habitat of Maule/Stefano Micheletti, Francisco Letelier Troncoso 


\section{Resultados y efectos del terremoto y del proceso de reconstrucción en comunas rurales de la región del Maule}

\author{
CARACTERIZACIÓN DEL PROCESO DE \\ RECONSTRUCCIÓN EN TÉRMINOS DE DAÑO, \\ DAMNIFICADOS Y AVANCES
}

Según información oficial, el sismo golpeó a nivel nacional a más de 900 pueblos y comunidades rurales y costeras. En el ámbito de la infraestructura y obras públicas, además de caminos, puentes y puertos, sufrieron daños 422 sistemas de agua potable rural, 27 caletas de pescadores, 6 colectores de aguas lluvia, 5 embalses y 8 riberas de cauces naturales ${ }^{26}$. En cuanto al adobe rural, resultaron destruidas 24.538 viviendas, 19.783 registraron daños mayores y 22.052 daños menores, por un total de $66.373^{27}$.

Sin embargo, tal como plantea el "Diagnóstico del Estado de la Reconstrucción - Terremoto y Tsunami del 27 de Febrero de 2010", publicado por la Delegación Presidencial para la Reconstrucción en el mes de junio de 2014: "la evidencia es que hasta la fecha no existen datos oficiales de población

26 Gobierno de Chile, 2010.

27 Ministerio Secretaría General de la Presidencia, 2011, p. 1.

\section{Consequences and Impact of the Earthquake and Recons- truction Process on the Rural Communes of Maule}

\author{
CHARACTERIZATION OF THE RECONSTRUCTION \\ PROCESS IN TERMS OF DAMAGE, VICTIMS AND \\ PROGRESS
}

According to official figures the earthquake struck more than 900 rural and coastal communities along the Chilean territory. In the field of infrastructure and public works, apart from roads, bridges and ports, 422 rural potable water systems, 27 stevedores, 6 rainwater collectors, 5 dams and 8 natural riverbanks were affected ${ }^{26}$. As for rural adobe, 24,538 housing units were destroyed, 19,783 dwellings suffered major damage and 22,052 received minor damage, thus totaling 66,373 damaged dwellings ${ }^{27}$.

However, according to the "Diagnostic of the State of Reconstruction - Earthquake and Tsunami, February 27, 2010" issued by the Presidential Delegation for the Reconstruction on June, 2014: "there has been no official data on the number

\footnotetext{
Gobierno de Chile, 2010.

Ministerio Secretaría General de la Presidencia, 2011, p. 1.
} 
TABLA 2. COMUNAS RURALES DE LA REGIÓN DEL MAULE.

\section{TABLE 2. RURAL COMMUNES LOCATED IN THE MAULE REGION.}

\section{Comunas rurales analizadas de la región del Maule}

Rural communes studied in the Maule Region

\begin{tabular}{|ccc}
\hline Chanco & Pelarco & Romeral \\
Colbún & Pelluhue & Sagrada Familia \\
Curepto & Pencahue & San Rafael \\
\hline Empedrado & Rauco & Vichuquén \\
Hualañé & Retiro & Villa Alegre \\
Licantén & Río Claro & Yerbas Buenas \\
\hline
\end{tabular}

Elaboración propia

Elaborated by the authors

rural afectada, y registro de los daños y pérdidas de la ruralidad más profunda simplemente no existen" ${ }^{\prime 2}$. No existe tampoco desagregación a nivel comunal de los datos para los sectores urbanos y rurales.

Para el análisis cuantitativo, y en función de la definición tomada en este estudio, se consideraron como "rurales" las comunas que se detallan en la tabla 2.

Delegación Presidencial para la Reconstrucción, 2014, p. 45. of rural dwellers affected or a record of damage or losses in isolated rural communities"28. It has also been impossible to find a communaloriented disaggregation of data on urban and rural sectors.

For the purposes of conducting a quantitative analysis, and according to the approach adopted by this research, the following communes have been regarded as part of the rural space (table 2).

Since the information obtained during the 2012 census is currently unavailable ${ }^{29}$, data on population and rural-related information was collected from the population projection for 2012 elaborated by the National Statistics Office, which was based on the 2002 census. Data related to victims, damaged dwellings and progress in the provision of housing was retrieved from the website of the Ministry of Housing and Urban Development ${ }^{30}$ (www.minvu.cl) and through a request for information enshrined in the Transparency Law. Such a request was satisfied on March, 2012, by the team in charge of the "Construction of Territorial Citizenship in Chile"

28 Delegación Presidencial para la Reconstrucción, 2014, p. 45.

29 According to a public declaration available at the website of this agency, the "National Statistics Office states that, on March 27, 2014, the access to information regarding the 2012 Population and Housing Census has been disabled. Such information was available at www.ine.cl and www.censo.cl".

30 Ministerio de Vivienda y Urbanismo, 2013-2014, p. 1. 
Los datos de población y de ruralidad utilizados son tomados de las proyecciones de población al año 2012 que realizó el Instituto Nacional de Estadísticas basándose en el Censo 2002, debido a que los datos del Censo 2012 no se encuentran actualmente disponibles ${ }^{29}$. Los datos relativos a damnificados, daños en las viviendas y avance en la entrega de obra se obtuvieron de la página web del Ministerio de Vivienda y Urbanismo ${ }^{30}$ (www. minvu.cl) y a través de una solicitud de información por Ley de Transparencia ingresada y respondida en marzo del año 2012 por el equipo del proyecto "Construcción de Ciudadanía Territorial en Chile"31, financiado por la Unión Europea y conformado por un consorcio de diversas organizaciones sociales del país, entre ellas la ONG Surmaule.

29 Según declaración pública disponible en su página web, el “Instituto Nacional de Estadísticas comunica que, con fecha 27 de marzo de 2014, ha procedido a deshabilitar el acceso a información del Censo de Población y Vivienda 2012, que a la fecha estaba disponible en el sitio web www.ine.cl y www.censo.cl".

30 Ministerio de Vivienda y Urbanismo, 2013-2014, p. 1.

31 Cabe señalarque junto con la dificultad para acceder a la información detallada del proceso de reconstrucción, se registraron incongruencias a veces marcadas en el tratamiento de la información en las diferentes bases de datos, y que por lo tanto el análisis propuesto no puede entenderse como una fotografía exacta de la realidad, sino solamente pretende identificar tendencias generales. project $^{31}$; an initiative funded by the European Union and composed of different local social organizations, including the NPO Surmaule.

\section{Level of Damage}

Being officially recognized as a victim represented the first major obstacle for those affected. It is possible to think that distance, dispersion and the difficulty in obtaining information -elements common to rural areas- have prevented an unknown number of rural victims from being recognized as such and receive State support. According to Fabian Perez, Regional Coordinator of the Presidential Delegation for the Reconstruction" ${ }^{32}$, this is a phenomenon "that has affected our coastal and valley regions and the communes located in the pre-Andean area".

31 It is worth pointing out that, apart from the poor access to information about the reconstruction process, there were some incongruences regarding the processing of information. This suggests that the proposed analysis should not be understood as a depiction of reality but as a means to identify general tendencies.

32 Appointed during the Bachelet administration, in office since March 11, 2014. 


\section{Nivel de daño}

La acreditación oficial de la condición de damnificado representó un primer obstáculo importante para la población afectada. Es posible pensar que debido a la distancia, dispersión y dificultad de acceso a la información que caracteriza a las zonas rurales, un número indefinido de damnificados de dichos sectores no ha podido acreditarse como tal para recibir el apoyo del Estado. Para Fabián Pérez, Coordinador Regional de la Delegación Presidencial para la Reconstrucción ${ }^{32}$, se trata de un fenómeno "transversal en el sector costero, en el sector de depresión intermedia de nuestra región y también en el sector de las comunas cercanas a la cordillera".

Tomando en cuenta el número de damnificados registrados hasta septiembre de 2010 (los que incluyen los hábiles e inhábiles de subsidio), queda en evidencia que en términos absolutos se han reconocido más damnificados en las comunas urbanas que en las rurales; sin embargo, si se analiza el número de damnificados en razón de la población, se observa mayor concentración del impacto del sismo en las

Nombrada durante el gobierno de Michelle Bachelet, que asumió el 11 de marzo de 2014.
Considering the number of registered earthquake victims as of September, 2010 (including eligible and non-eligible subsidy recipients), it is clear that -in absolute terms - the number of registered victims from urban communes is larger than the number of victims from rural areas. However, the percentage analysis of the number of victims in terms of population reveals that the impact of the earthquake on rural communes (10.3 percent) doubled the damage suffered by urban communes (5.3 percent).

Once registered as a victim, the second obstacle faced by those affected was related to the subsidy eligibility criteria proposed by the Ministry of Housing and Urban Planning ${ }^{33}$, which determined the number of candidates eligible for support from reconstruction programs such as the Housing Solidarity Fund, the Program on the Protection of Family Heritage and the Housing Subsidy for Middle-Income Groups (Supreme Decree No. 40).

Therefore, it is worth analyzing the information regarding the number of eligible victims (as

33 Being declared as victim and having such a condition registered at the local municipality; being over 18 years of age; applicants or spouses should not be owners of other dwellings or have a valid subsidy certificate; having a Social Protection Card; and certify the availability of land in the event of building a dwelling in the site owned by beneficiaries. (Source: Ministerio de Vivienda y Urbanismo, no date). 
comunas rurales (10,3\%), llegando casi a doblar el nivel de daño urbano en términos porcentuales (5,3\%).

Una vez efectuado el registro como damnificado, la segunda barrera que tuvo que enfrentar la población afectada, fueron los criterios propuestos por el Ministerio de Vivienda y Urbanismo para ser sujetos hábiles de subsidio ${ }^{33}$, los que determinaban la habilitación para recibir el apoyo de los programas destinados a la reconstrucción, es decir el Fondo Solidario de Viviendas, el Programa de Protección del Patrimonio Familiar y el Subsidio Habitacional para los Sectores Medios (Decreto Supremo 40).

Vale la pena entonces revisar los datos relativos a la cantidad de damnificados hábiles (hasta el año 2011) ${ }^{34}$, relacionándola con el total de damnificados registrados; se puede así apreciar cómo el porcentaje de damnificados hábiles, en función del total de damnificados registrados, es bastante menor en las comunas rurales (69,4\%) que en las comunas urbanas $(78,8 \%)$.

Esto puede explicarse a través de diferentes hipótesis, entre ellas las características propias de una ruralidad más dispersa y aislada. Para Pérez, una dificultad importante en esta etapa fue la gran cantidad de sucesiones y propiedades informales de

33 A saber: ser damnificado por la catástrofe y tener acreditada esta condición en su municipalidad, ser mayor de 18 años, el postulante 0 su cónyuge no pueden ser propietarios de otra vivienda ni tener un certificado de subsidio vigente, contar con Ficha de Protección Social y acreditar disponibilidad de terreno, en caso de construcción en sitio propio (Fuente: MINVU, s.f.).

34 Se trata de una cifra definitiva, que no ha variado posteriormente. of $2011^{34}$ ) through a comparison with the total number of registered victims. This would allow us to observe how the percentage of eligible victims in terms of the total number of registered victims is considerably lower in rural communes (69.4 percent) than in urban communes (78.8 percent).

Different hypotheses such as those related to the features common to disperse and isolated areas can explain the above phenomenon. According to Perez, successions and informal property represented a significant difficulty during this phase: "another complicated issue was related to the fact of regularizing their lands in order to provide and build new houses". On the other hand it was suggested that poor access to information played a key role in this matter since "people make good decisions if they are properly informed and such a task is the responsibility of public entities"; however, public officials "were overloaded with duties and this opportunity did not exist".

A second level of analysis refers to the categorization of damage to dwellings which,

34 This is a definitive figure that has not been modified. 
terreno que existe en estas zonas: "otra dificultad era limpiar el terreno de ellos, limpiar en términos formales, de papeles, para poder llevar una casa y poder reconstruir". Por otro lado, plantea que jugó un rol fundamental también el escaso acceso a la información, ya que "la gente toma, buenas decisiones si está bien informada, y esta es pega del aparataje público", pero el funcionario público "se vio sobrepasado y este espacio no estuvo".

Un segundo nivel de análisis, se refiere a la caracterización de la tipología del daño sufrido, que según los datos del Ministerio de Vivienda y Urbanismo se divide entre las viviendas que resultaron reparables y no reparables, lo que se detalla en la tabla 3.

También en este caso se aprecia una mayor cantidad de viviendas dañadas en las comunas urbanas, sin embargo, si se relaciona el número de familias con vivienda inhabitable con el total de familias damnificadas, se puede apreciar cómo en lo rural el daño ha sido mucho más definitivo, según se detalla en la tabla 4. Probablemente, esta diferencia se debe a la gran cantidad de construcciones en adobe.

Es posible apreciar cómo en las comunas rurales la proporción de propietarios es bastante menor, lo que posiblemente se debe al más bajo nivel de formalización de tenencias característico del campo (especialmente por el tema de las sucesiones) y expone potencialmente al territorio a la expulsión de damnificados de su localización originaria. according to data provided by the Ministry of Housing and Urban Development, was divided into repairable and non-repairable (table 3).

In this case it is also possible to observe that the largest portion of damaged dwellings was located in urban communes; however, the comparison between the number of families with non-repairable houses and the total number of affected families reveals that the rural dimension was the area most affected by this event (table 4). Such a difference may be explained by the presence of large numbers of adobe houses.

The above table shows that the lowest portion of homeowners is concentrated in rural communes; this may be due to low tenure regularization, which is a characteristic common to rural areas (especially in the case of successions). Such a situation may be translated into the eviction of victims from their original places of residence.

As for reconstruction, quarterly data provided by the Ministry of Housing and Urban Development allows us to measure the progress made in this regard according to the number of delivered dwellings, under-construction dwellings or future dwellings (table 5). For the purposes of this analysis, the number of delivered dwellings is compared with the number of total dwellings included over three different periods of time. 
TABLA 3. CARACTERIZACIÓN DEL DAÑO DE VIVIENDAS SEGÚN COMUNAS RURALES Y URBANAS. TABLE 3. CATEGORIZATION OF DAMAGE TO DWELLINGS ACCORDING TO RURAL AND URBAN COMMUNES

\begin{tabular}{|c|c|c|c|}
\hline Comunas urbanas & & Comunas rurales & \\
\hline Urban communes & & Rural communes & \\
\hline Familias con vivienda no reparable & Familias con vivienda reparable & Familias con vivienda no reparable & Familias con vivienda reparable \\
\hline $\begin{array}{l}\text { Families with non-repairable } \\
\text { houses }\end{array}$ & Families with repairable houses & $\begin{array}{l}\text { Families with non-repairable } \\
\text { houses }\end{array}$ & Families with repairable houses \\
\hline 25.855 & 16.039 & 16.446 & 4.307 \\
\hline $62 \%$ & $38 \%$ & $79 \%$ & $21 \%$ \\
\hline
\end{tabular}

Elaboración propia y datos del MINVU.

Elaborated by the authors according to data retrieved from MINVU

TABLA 4. DAMNIFICADOS URBANOS Y RURALES SEGÚN TIPOLOGÍA. TABLE 4. URBAN AND RURAL VICTIMS ACCORDING TO HOUSING TENURE

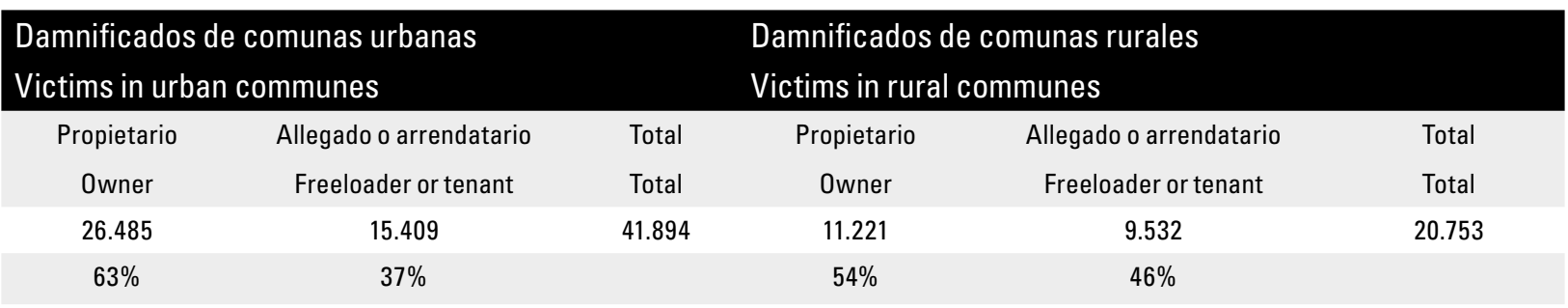

Elaboración propia y datos del MINVU.

Elaborated by the authors according to data retrieved from MINVU 
TABLA 5. AVANCES DEL PROCESO DE RECONSTRUCCIÓN. TABLE 5. PROGRESS MADE DURING THE RECONSTRUCTION PROCESS.

\begin{tabular}{|c|c|c|c|c|c|c|}
\hline \multirow[t]{3}{*}{$\begin{array}{l}\text { Fecha } \\
\text { Date }\end{array}$} & \multicolumn{3}{|l|}{$\begin{array}{l}\text { Comunas Urbanas } \\
\text { Urban communes }\end{array}$} & \multicolumn{3}{|l|}{$\begin{array}{l}\text { Comunas Rurales } \\
\text { Rural communes }\end{array}$} \\
\hline & Obras entregadas & Obras totales & Avance & Obras entregadas & Obras totales & Avance \\
\hline & Delivered dwellings & $\begin{array}{l}\text { Total number of } \\
\text { dwellings }\end{array}$ & Progress & Delivered dwellings & $\begin{array}{l}\text { Total number of } \\
\text { dwellings }\end{array}$ & Progress \\
\hline Sep 2013 & 29.466 & 37.231 & $79 \%$ & 10.975 & 14.725 & $75 \%$ \\
\hline Feb 2014 & 35.518 & 39.269 & $90 \%$ & 12.883 & 15.190 & $85 \%$ \\
\hline Jun 2014 & 36.510 & 41.112 & $89 \%$ & 13.574 & 15.745 & $86 \%$ \\
\hline
\end{tabular}

Elaboración propia y datos del MINVU

Elaborated by the authors according to data retrieved from MINVU

En cuanto a los avances de reconstrucción, según la información entregada por el Ministerio de Vivienda y Urbanismo que se detalla en la tabla 5, se pueden medir en función de la cantidad de obras entregadas, en ejecución y por iniciar, detalle que se publicó trimestralmente. Para este análisis, se compara el número de obras entregadas en función de las obras totales presupuestadas en tres momentos diferentes.

El reporte más reciente, de noviembre de 201435 confirma la tendencia, ya que para las comunas urbanas la relación entre obras terminadas y

35 No se agregan los datos a la tabla debido al cambio de nomenclatura introducido en el reporte de noviembre de 2014 (obras terminadas/obras entregadas).
The most recent report, which was issued on November, 2014 ${ }^{35}$, confirms the above tendency since in urban and rural communes the relationship rate between the number of completed dwellings and active subsidies is 93 and 90 percent, respectively.

To conclude this phase of quantitative analysis it is safe to say that, in relative terms, rural communes were the areas most affected by this event when compared to urban communes and the percentage of victims eligible for subsidies is smaller than the total number of registered victims. Likewise, rural areas have the highest rates of non-repairable dwellings and victims

35 No data was added to this Table since the modifications made to the nomenclature on the report issued on November, 2014 (completed dwellings/delivered dwellings). 
subsidios vigentes es del 93\% y para las comunas rurales del $90 \%$.

Para cerrar esta etapa de análisis cuantitativo, es posible concluir que en términos relativos las comunas rurales han sido mucho más afectadas que las comunas urbanas y que existe un porcentaje menor de damnificados sujetos de subsidios respecto del total de damnificados registrados. A la vez, presentan índices mayores de viviendas no reparables y de damnificados no propietarios, lo que agudiza su vulnerabilidad.

\section{Efectos del proceso de reconstrucción en los sectores rurales}

\section{INEOUIDAD EN EL ACCESO A LOS REGISTROS}

A nivel general el proceso de reconstrucción ha presentado graves problemas de registro de daños y de afectados; de hecho, para dimensionar e identificar a la población damnificada se utilizaron al menos tres instrumentos diferentes, que en la práctica no dialogaron entre sí: la Ficha EFU (Encuesta Familiar Única de Emergencia), el Registro de Damnificados y el Registro de Reconstrucción. who do not own a property, this being a situation that increases the vulnerability of this sector.

\section{Consequences of the Reconstruction Process on Rural Sectors}

\section{INEQUALITY OF ACCESS TO RECORDS}

In general terms the reconstruction process has involved serious problems in the development of a record of damage and victims; in fact, three different instruments were used to measure and identify those affected by the earthquake: the Unique Emergency Family Survey (UEFS), the Record of Victims and the Reconstruction Record.

According to the Presidential Delegation for the Reconstruction ${ }^{36}$ "it is also probable that most vulnerable victims may have never been registered in records since their vulnerability condition prevents them from being included in welfare services". Strictly speaking, "evidence shows that there is still no data regarding the official number of rural victims or a registry of damage or losses in rural areas".

36

Delegación Presidencial para la Reconstrucción, 2014, p. 28. 
Según menciona la Delegación Presidencial para la Reconstrucción, ${ }^{36}$ "también es probable que los damnificados más vulnerables nunca hayan formado parte de los registros, porque dada su condición de vulnerabilidad suelen mantenerse alejados de los servicios existentes".

\section{INEQUIDAD EN EL ACCESO A VIVIENDAS DE EMERGENCIA Y SUBSIDIOS DE REPARACIÓN Y/O RECONSTRUCCIÓN.}

Según señalan la Cruz Roja, Moreno y Valenzue$1 \mathrm{a}^{37}$, se vivieron situaciones de exclusión de familias rurales acceso a viviendas de emergencia y subsidios de reparación y/o reconstrucción.

Respecto de la escasa capacidad de respuesta a la demanda de subsidios de reconstrucción y reparación en zonas rurales, la exclusión se asoció a dos condiciones: "por una parte, familias que efectivamente no han recibido un subsidio habitacional y por otra parte, familias que pese a que se les ha asignado un subsidio habitacional, no han podido hacer uso de éste"38. En este caso, la Cruz Roja y la Universidad de Concepción identificaron factores:

Delegación Presidencial para la Reconstrucción, 2014, p. 28.

Rojas, Moreno y Valenzuela, 2011, p. 33. $\begin{array}{ll}37 & \text { Rojas, } \\ 38 & \text { Ibíd. }\end{array}$

44 revista invi № 86 / Mayo 2016 / Volumen $N^{0} 31:$ 17-58

\section{INEQUALITY OF ACCESS TO EMERGENCY HOUSING UNITS AND REHABILITATION OR RECONSTRUCTION}

According to the Red Cross and the University of Concepcion $^{37}$, some rural families were excluded from the access to emergency housing units and rehabilitation or reconstruction subsidies.

As for the poor capacity for response within the context of the demand for reconstruction or reparation subsidies, exclusion was associated with two conditions: "on the one part, families that have not received housing subsidies and, on the other hand, families that have been unable to use already allocated housing subsidies" 38 . In this case the Red Cross and the University of Concepcion identified the following factors:

- institutional management, bureaucracy, poor institutional capacities, lack of coordination and lack of fieldwork

- problems related to the regularization of land and cultural characteristics of rural families

- once again, isolation and problems in the access to information

37 Rojas, Moreno and Valenzuela, 2011, p. 33.

38 Ibid. 
- gestión institucional, burocracia, insuficiente capacidad institucional, descoordinación y falta de trabajo en terreno;

- problemas de saneamiento de terrenos y características culturales de las familias que residen en zonas rurales, $y$

- una vez más, las condiciones de aislamiento y los problemas de acceso a la información.

\section{DEFICIENTE ACCESO AL MERCADO DE SOLUCIONES}

El escaso interés de las grandes empresas constructoras por emprender obras en sitios propios de territorios rurales, llevó a que el proceso de reconstrucción se desarrollara de forma más lenta. Uno de los efectos más evidentes de ello fue el abandono de obras en construcción en sectores rurales por parte de diversas empresas contratistas, una situación que ha sido denunciada en diferentes ocasiones en la Región del Maule. Las comunas más afectadas han sido San Clemente ${ }^{39}$, donde a marzo de 2013 existían 200 familias cuyas obras

39 San Clemente (...), 2013.

\section{INADEQUATE ACCESS TO SOLUTION MARKETS}

The lack of interest of building firms to work in rural areas on plots owned by local people slowed down the pace of the reconstruction process. One of the clearest examples of this issue was the abandonment of rural projects that were still in progress; this situation has been denounced by people from the Maule Region. Some of the most affected communes are San Clemente ${ }^{39}$-where 200 families had been affected by the abandonment of projects as of March, 2013-, Villa Prat ${ }^{40}-100$ families affected - and San Rafael. ${ }^{41}$

According to "Rural Reconstruction under Judgment", a report broadcast by Television Nacional de Chile - Red Maule on March, 201342, 980 out of 12,000 subsidies for reconstruction of dwellings in lands owned by local people were abandoned by contractors. This is explained by the fact that large building firms delegated responsibilities to some of the 400 small local contractors that do not have enough resources to undertake reconstruction tasks in rural areas, the 
habían sido abandonadas, Villa Prat ${ }^{40}$ con 100 familias y San Rafael ${ }^{41}$.

Según información entregada en el reportaje de Televisión Nacional de Chile - Red Maule ${ }^{42}$, en la VII Región se habían entregado 12.000 subsidios para reconstrucción en sitios propios de sectores rurales, de los cuales 980 presentaron problemas de abandono de obras por parte de las constructoras. Esto puede ser explicado por el hecho de que dado el desinterés de grandes empresas constructoras, las obras se han entregado muchas veces a alguno de los 400 pequeños y medianos contratistas locales que no tienen la solvencia económica para enfrentar el proceso de reconstrucción en zonas rurales, y por lo tanto al poco andar se produce el abandono de obras. Los damnificados se encuentran entonces con obras a medio terminar, que permanecen sin avances durante meses.

Aunque el Servicio de Vivienda y Urbanización no tenga la obligación de llevar un registro específico, según información entregada por este servicio $^{43}$, el 17 de octubre de 2013 señalaba que "se han efectuado 383 liquidaciones de contratos, mediante la modalidad de término unilateral por incumplimiento del contratista por abandono de

40 http://www.redmaule.com/denuncian-abandono-de-obras-enreconstruccion-de-zonas-rurales-del-maule/.

41 Crónica (...), 2013.

42 Ibíd.

43 SERVIU Región del Maule, 2013. result being the abandonment of projects. Victims are left with unfinished dwellings for months.

Despite the fact that the Housing and Urban Development Service is not responsible for the elaboration of a register, information provided by this entity revealed that, as of October 17, 2013 ${ }^{43}$, " 380 contracts were unilaterally terminated due to a breach of agreement on the part of building firms ${ }^{\prime 24}$.

Finally, it is worth pointing out that according to a report issued by the Ministry of Housing and Urban Development on November, 2014, a large number of finished projects have not been registered by the respective Departments of Municipal Works: 5,791 in the case of rural communes and 7,014 in the case of urban communes. The latter one demonstrates the significant —and proportional-vulnerability of rural communities.

43 SERVIU Región del Maule, 2013.

44 These terminations of contract are detailed as follows: Cauquenes, 65 dwellings; Chanco, 29; Colbun, 3; Curepto, 16; Licanten, 2; Linares, 5; Longavi, 19; Maule, 7; Parral, 13; Pelarco, 7; Pelluhue, 6; Retiro, 41; Rio Claro, 33; Sagrada Familia, 26; San Clemente, 54; San Javier, 11; San Rafael, 33; Talca, 12; and Villa Alegre, 1. 
obras, de acuerdo a las facultades establecidas en el respectivo contrato de construcción" ${ }^{\text {"44 }}$.

Finalmente, cabe señalar que en el reporte de noviembre 2014 del Ministerio de Vivienda y Urbanismo aparece un dato muy relevante que se refiere a la gran cantidad de obras terminadas sin recepción de las respectivas direcciones de obras Municipales: para las comunas rurales son 5.791 viviendas y para las urbanas 7.014, lo que demuestra una vez más la mayor vulnerabilidad -en términos proporcionales- de las comunidades que viven en las primeras.

\section{EL FRACASO DEL SUBSIDIO DE AUTOCONSTRUCCIÓN ASISTIDA}

El subsidio de autoconstrucción que se introdujo en 2011 como medida extraordinaria para abordar específicamente la situación rural, produjo un impacto relativamente escaso. Esta modalidad se orientó en términos teóricos a generar soluciones donde era más difícil llegar con empresas constructoras, para autoconstruir una vivienda en un sitio de propiedad del beneficiario, con asesoría técnica asignada por el Servicio de Vivienda y Urbanismo;

44 Dichas liquidaciones se individualizan en las siguientes comunas: Cauquenes 65 viviendas, Chanco 29, Colbún 3, Curepto 16, Licantén 2, Linares 5, Longaví 19, Maule 7, Parral 13, Pelarco 7, Pelluhue 6, Retiro 41, Río Claro 33, Sagrada Familia 26, San Clemente 54, San Javier 11, San Rafael 33, Talca 12 y Villa Alegre 1 vivienda.

\section{THE FAILURE OF THE ASSISTED SELF-HELP CONSTRUCTION SUBSIDY}

The subsidy for self-help construction was implemented in 2011 as an extraordinary measure intended to specifically address the rural issue; such an initiative had a limited impact. In theoretical terms, this measure focused on the areas that were difficult to access for construction firms and enabled victims who owned plots of land to build dwellings on their own with technical assistance provided by the Housing and Urban Development Service. This initiative also operated in unregulated lands.

However, as of September, 2013, and considering the three regions most affected by the earthquake (O'Higgins, Maule and Bio Bio), only 924 subsidies for self-help construction had been allocated. This figure included other subsidies unrelated to reconstruction programs. Likewise, only 381 out of the 924 subsidies had successfully been implemented ${ }^{45}$.

Apart from rehabilitation programs, there were 12,000 reconstruction subsidies intended to be exclusively allocated in the rural areas of Maule.

45 Ministerio de Vivienda y Urbanismo, 2013. 
ello, permitiendo además operar en terrenos que no estuvieran totalmente regularizados.

Sin embargo, a septiembre de 2013 y sumando la tres regiones más afectadas por el terremoto (O’Higgins, Maule y Bío Bío), el número de subsidios de autoconstrucción asignados era solamente de 924, entre los cuales se encontraban además subsidios que no pertenecían al programa de reconstrucción. A la misma fecha, de los 924 subsidios otorgados, solamente estaban terminadas 381 obras $^{45}$.

Ahora bien, en el Maule se otorgaron alrededor de 12.000 subsidios de reconstrucción en zonas netamente rurales (sin contar los de reparación), de los cuales solamente 363 fueron de autoconstrucción asistida. Posteriormente, 72 damnificados renunciaron o cambiaron de programa -lo que indica posibles problemas en la implementación de alguna fase del proceso, especialmente en la fase de acompañamiento-, por lo cual el número definitivo de subsidios en modalidad autoconstruida fue de 288, algo como el 2,4\% del total. A noviembre de 2013 se habían terminado 187 obras en toda la región: a todas luces, un impacto muy pobre si se considera que la medida fue presentada como "la solución" para las zonas rurales.

Ministerio de Vivienda y Urbanismo, 2013.
Of this number, only 363 subsidies corresponded to assisted self-help construction initiatives. Then, 72 victims relinquished or moved to other programs - thus indicating possible issues at some implementation phase throughout the project, especially during the assistance phasewhich reduces the number of beneficiaries to 288 (representing 2.4 percent of total subsidies). As of November, 2013, a total of 187 projects had been completed in the Maule Region: there is no doubt about the poor impact of this initiative, especially when considering that this measure was intended to "solve" the issues of rural areas.

\section{LACK OF RELEVANCE WITHIN THE CONTEXT OF HOUSING SOLUTIONS FOR RURAL AREAS}

Such a lack of relevance emerged due to the recurring thought that urban social units were suitable for rural families.

The above does not only refer to the composition and dimensions of dwellings but also to their structure as a whole (getting accustomed to have close neighbors) and the availability of land to carry out rural activities such as the cultivation of family vegetable gardens, the breeding of small animals, etc. 


\section{FALTA DE PERTINENCIA DE LAS SOLUCIONES HABITACIONALES PARA LOS SECTORES RURALES}

La falta de pertinencia de las soluciones habitacionales, se ha presentado en el proceso de reconstrucción en sitio propio, debido a la insistencia en pensar que la tipología de la vivienda social urbana es apropiada para las familias rurales.

No se trata solamente de la materialidad y el tamaño de las viviendas, sino de su conformación como conjunto (acostumbrarse a tener vecinos tan cercanos) y de disponibilidad de suelo en el sitio para soportar prácticas rurales como el cultivo de huertas familiares, la crianza de pequeños animales, etc.

La falta de pertinencia es entonces representada por un conjunto de elementos, que viene dado por:

- relocalización,

- reducción del tamaño,

- distribución de la vivienda,

- imposición de una idea urbana de barrio o villa,

- imposición de la idea de vivienda = familia nuclear, y
Therefore, this lack of relevance is represented by elements such as:

- relocation

- reduction in the dimension of dwellings

- composition of dwellings

- prevalence of urban-oriented ideas about neighborhoods or villages

- prevalence of the concept that refers to the concept of dwelling as a nuclear family, and

- transformation of the relationship between housing and land.

In this sense, while the housing provided by policies can be seen as an improvement regarding harsh living conditions (thermal and sound insulation, service availability, etc.), some soft and socio-cultural conditions are affected ${ }^{46}$.

\section{RURAL-URBAN MIGRATION AND LOSS OF ASSETS}

One the most evident and complex aspects of this issue is associated with the increase in "ruralperiphery" migration, which resulted from the pressure exerted by the reconstruction model to

46 Observatorio de Ruralidad, 2014, p. 3. 
- transformación de la relación de la vivienda con la tierra.

En este sentido, si bien la vivienda sólida que propone la política puede ser vista como una mejora en condiciones duras de habitabilidad (aislación térmica y sonora, disponibilidad de servicios, etc.), hay condiciones blandas o socioculturales que resultan dañadas ${ }^{46}$.

\section{LOS DESPLAZAMIENTOS CAMPO - CIUDAD Y PÉRDIDA DE ACTIVOS}

Uno de los efectos más evidentes y complejos ha sido la profundización de la migración "campo-periferia”, debido a la presión instalada por el modelo de reconstrucción para concentrar la demanda de vivienda en villorrios o en las zonas periféricas de las ciudades y pueblos cercanos. Esta tendencia, que ya se estaba desarrollando antes del terremoto, se vio reforzada considerando que en las comunas rurales al menos el $27 \%$ de los subsidios entregados correspondió a la modalidad de adquisición de vivienda construida.

46 Observatorio de Ruralidad, 2014, p. 3 concentrate the demand for housing in villages or peripheral areas of cities and neighboring towns. Such a tendency, which had already emerged before the earthquake, was intensified by the fact that less than 27 percent of allocated subsidies in rural communes corresponded to the subsidy for the purchase of dwellings.

In the case of the Maule Region, 38 percent of the housing replacement subsidies allocated in the 18 rural communes involved the relocation of families (4,902 cases); there are also $46 \mathrm{new}$ housing development projects, each one at different levels of progress ${ }^{47}$.

On the other hand, according to an analysis conducted by the Center for Urban-Territorial Studies (CUTS) which focused on 12 new housing developments built in Talca ${ }^{48}$ after the earthquake (information issued by SERVIU with data provided by CEUT and Surmaule), it is possible to observe that a third of dwellers come from rural communes located around Talca. Table 6 shows the communes of origin of dwellers.

\footnotetext{
47 SERVIU Región del Maule, 2014.

48 Analysis about the location of dwellers of post-earthquake social housing in Talca (Altos del Estero I, II and III; Comite de Adelanto Monseñor Manuel Larrain; Don Andres III; Comite Social Dionisio Astaburuaga; Nuevo Amanecer Los Maitenes; Villa el Parque II and III, Don Sebastian II de Colin; Don Sebastian I; Villa Jardin del Norte; and Villa del Prado.
} 
En el caso de la Región del Maule, el 38\% del total de los subsidios asignados para la reposición de viviendas en las 18 comunas rurales implicó la relocalización de las familias (4.902 casos), y existen 46 nuevos proyectos de conjuntos de vivienda con diferentes estados de avance ${ }^{47}$.

Por otro lado, según el análisis del Centro de Estudios Urbano-Territoriales para la Región del Maule (CEUT) sobre 12 nuevos conjuntos habitacionales de $\mathrm{Talca}^{48}$ que se construyeron post terremoto (información del SERVIU y elaboración datos de CEUT y Surmaule), se puede apreciar que, en suma, un tercio de los pobladores proceden de las comunas aledañas a Talca, en su mayoría rurales. En la tabla 6 se especifican las procedencias por comuna.

Cabe destacar que la pérdida de activos no se limita a lo patrimonial, sino también afecta ámbitos como la localización, que permitía a los damnificados cercanía con sus fuentes laborales y sus redes de apoyo, tanto familiares como amicales. La vivienda, por otro lado, constituye un patrimonio que cumple diversas funciones: habitación, socialización y funciones productivas.

47 SERVIU Región del Maule, 2014

48 Análisis de localización anterior de residentes de conjuntos de viviendas social es post-terremoto en Talca (Altos del Estero I, II y III, Comité de Adelanto Monseñor Manuel Larraín, Don Andrés III, Comité Social Dionisio Astaburuaga, Nuevo Amanecer, Los Maitenes, Villa El Parque II y III, Don Sebastián II de Colín, Don Sebastián I, Villa Jardín del Norte y Villa del Prado.
It is worth pointing out that the loss of assets does not only refer to heritage but also to location, which allowed victims to live near their workplaces and support networks, both at family and friends levels. Housing, on the other hand, is a heritage that performs different functions such as inhabitation, socialization and productive activities.

\section{Conclusions}

Post-earthquake housing policies operated through the existing institutional system and funded the replacement of dwellings, ignoring the complexity underlying the reconstruction of habitat, understood as heritage with its own technologies, forms and customs.

Rural sectors of the Maule Region were not only affected by this natural catastrophe, but also by a series of neoliberal public policies that triggered the radicalization of the centralist, sectoral and urban nature of the reconstruction process. In this context there was a violation of human rights, 
TABLA 6. PROCEDENCIA DE POBLADORES DE CNT POST TERREMOTO SEGÚN COMUNA DE ORIGEN.

\section{TABLE 6. COMMUNES OF ORIGIN OF DWELLERS INCLUDED IN POST-EARTHOUAKE CNS PROGRAMS.}

\section{Comuna Pobladores (Núcleos familiares) \\ Commune Dwellers (Family units)}

\begin{tabular}{ll|}
\hline Talca & 661 \\
\hline Maule & 158 \\
Pencahue & 81 \\
Constitución & 28 \\
\hline San Clemente & 19 \\
\hline Pelarco & 11 \\
\hline San Rafael & 9 \\
\hline Curepto & 8 \\
\hline San Javier & 5 \\
\hline Cauquenes & 5 \\
\hline Licantén & 3 \\
\hline Curicó & 3 \\
\hline Chanco & 3 \\
\hline Longaví & 2 \\
\hline Sagrada Familia & 1 \\
\hline Empedrado & 1 \\
\hline Pelluhue & 1 \\
\hline Parral & 1 \\
\hline Yerbas Buenas & 1 \\
\hline
\end{tabular}

Elaboración propia.

Elaborated by the authors. defined as essential during natural disasters events by different international organizations (IASC, UN, etc.). These rights are related to the accessibility, affordability, habitability, cultural adequacy and convenience of location criteria that should be met by the dwellings provided by the State, including the right of the civil society to participate in this process.

The infringement of the above rights increased the vulnerability of rural habitats and, unlike in the case of urban zones, the communes located in these areas had to face a complex reconstruction process that involved obvious discrimination in terms of the provision of emergency dwellings and allocation of subsidies. The consequences of such events were associated with two substantial aspects: loss of identity and heritage, and the intensification of rural-urban migration.

The difficulty to attract demand and the dispersion, access and communication issues common to rural areas turned the reconstruction of these zones into an unattractive business for private actors. Likewise, a lack of relevance for ecology and identity emerged in the cases where rural victims were assisted by the market since the dwellings provided by the State had almost no relationship with the traditional purposes and dimensions of rural housing. 


\section{Conclusiones}

Las políticas públicas post-terremoto operaron en Chile a través de la institucionalidad existente financiando la reposición de viviendas, pero sin hacerse cargo de las complejidades que significaba la reconstrucción de un hábitat, entendido como un patrimonio con tecnologías, formas y hábitos propios.

Los sectores rurales de la Región del Maule se vieron afectados no solamente por la catástrofe natural, sino también por una serie de políticas públicas de corte neoliberal, que determinaron una radicalización de la perspectiva centralista, sectorial y urbana del proceso de reconstrucción. En este contexto se obviaron los principios de derechos humanos que diferentes organismos de nivel internacional (IASC, ONU, etc.) definen como centrales en situación de desastre natural y que dicen relación con los criterios de accesibilidad, asequibilidad, habitabilidad, adecuación cultural y conveniencia de ubicación de las viviendas que el Estado proporcionó y del derecho de participación de la sociedad civil en el proceso.

Esta conculcación de derechos provocó un aumento de la vulnerabilidad del hábitat rural y las comunidades de estos sectores tuvieron que enfrentar un proceso de reconstrucción mucho más complejo que sus pares urbanas, sufriendo además discriminaciones evidentes en la entrega de viviendas
Considering that the State delegated the provision of housing solutions to the real estate market, the alternatives to affected rural families were restricted to the provision of prefabricated dwellings and self-help construction (a measure that was based on standard models which had a limited impact). The modification of the housing typology had a negative effect on the identity and traditional aspect of different towns since this is a central element of rural life, which is a space where culture and function converge.

On the other hand, while it has been historically seen as a search for opportunities, the ruralurban migration process has been intensified by construction firms, who aim at producing economies of scale through either the concentration of dwellings in semi-rural villages or the construction of large housing developments in intermediate cities such as Talca or Curico.

Post-earthquake rural-urban migration, which is a phenomenon that has been clearly observed in the case of the Construction in New Sites (CNS) program, does not only imply the depopulation of country areas and the subsequent modification in the life styles of newly arrived families but also refers to the increased precariousness of those who stay in the rural sphere. Displacements 
de emergencia y en la asignación de subsidios. Los efectos generados redundaron en dos aspectos sustantivos: pérdida de identidad y patrimonio y aceleración del proceso de migración hacia la ciudad.

La dificultad en la captación de la demanda, su dispersión y las dificultades de acceso y comunicación en la zona rural, hicieron que reconstruir en el campo no representara un negocio atractivo para los actores privados. Ahora bien, en los casos en que los damnificados rurales fueron atendidos por el mercado, se develó la poca pertinencia ecológica e identitaria de la oferta habitacional subsidiada por el Estado, tratándose de viviendas que poco tenían que ver con el tipo de uso y los tamaños tradicionales.

Con un Estado que dejó en manos del mercado la provisión de soluciones, las alternativas para las familias rurales damnificadas se redujeron, en la práctica, a la vivienda tipo (prefabricada) y a la autoconstrucción asistida (que tuvo un impacto menor y que operó con modelos estandarizados). La modificación de la tipología de vivienda afectó negativamente la identidad de las diversas localidades y su imagen tradicional, ya que representa un elemento central de la vida rural, donde confluye cultura y función.

Por otro lado está la intensificación de los procesos migratorios hacia lo urbano, que si bien tiene como motivación histórica la búsqueda de mejores

54 revista invi № 86 / Mayo 2016 / Volumen $N^{0}$ 31: 17-58 disrupt the family and social networks that sustained large share of daily life.

The act of inhabiting rural areas, which is regarded as having heritage value with its own technologies, forms and customs ${ }^{49}$, was clearly sacrificed during the reconstruction process in order to accelerate the replacement of dwellings and increase profits from the provision of housing units. Likewise, the work capacity of rural people as well their knowledge about traditional construction techniques and the sense of reciprocity that generates cooperation and mutual assistance were all lost.

The effects described throughout this paper reveal that the violation of certain rights caused by reconstruction policies have increased the precarious conditions of rural areas located in the Maule Region. In this sense, there is a need to develop tailored policies intended to mitigate these problems and set the guidelines for future interventions focused on relevant social and cultural issues. The new Program of Rural Habitability, which is currently being developed by the Chilean government in order to improve the habitability conditions of rural and middleincome families who live in rural locations of up to 2,000 inhabitants, will confirm if the

49 Piga, 2011, p. 147. 
oportunidades de vida en la ciudad (respecto de una ruralidad donde existen pocas oportunidades), fue acelerada por la tendencia de las empresas constructoras a producir economías de escala, ya sea a través de la aglomeración de viviendas en villorrios semi rurales o construyendo grandes stock de vivienda en zonas periféricas de ciudades intermedias como Talca o Curicó.

Los procesos migratorios campo-ciudad post-terremoto, evidenciados de manera clara en el caso de los proyectos de Construcción en Nuevos Terrenos (CNT), no solo implican el despoblamiento del campo y la consecuente modificación de las formas de vida de las familias que llegan a la ciudad, sino también la precarización de la vida para quienes se quedan en lo rural. Los desplazamientos producen el desmembramiento de redes familiares y sociales que sustentaban buena parte de la vida cotidiana.

Si el modo de habitar rural es propiamente un patrimonio, con tecnologías, formas y hábitos asociados $^{49}$, es evidente que este aspecto se sacrificó durante la reconstrucción, en función de acelerar la reposición de vivienda y de aumentar los márgenes de utilidad en la provisión de unidades. Se desperdició al mismo tiempo la capacidad de trabajo de la gente del campo, su conocimiento en técnicas tradicionales de construcción y el sentido post-earthquake process has integrated some learning experiences into these fields.

Above all, there is an urgent need to develop a rural-oriented project intended to provide material and symbolic solutions for the establishment of dwellers and the repopulation of these areas. 
de reciprocidad que genera circuitos de cooperación y ayuda mutua.

Los efectos descritos demuestran entonces que las políticas de reconstrucción, al vulnerar ciertos principios de derechos, han profundizado las precariedades de los sectores rurales de la Región del Maule. En este sentido se ratifica la necesidad de hacer un esfuerzo importante por desarrollar políticas específicas que puedan mitigar lo ocurrido, y proyectar a futuro mejores intervenciones, más pertinentes social y culturalmente. El nuevo Programa de Habitabilidad Rural, que el gobierno chileno está diseñando para mejorar las condiciones de habitabilidad de familias vulnerables y de sectores medios que residen en entidades rurales de hasta 2.000 habitantes, dirá si el proceso postterremoto ha permitido integrar algún aprendizaje en estos ámbitos.

Pero por sobre eso, sigue siendo urgente la necesidad de construir un proyecto de ruralidad que ofrezca condiciones materiales y simbólicas que promuevan la radicación de sus habitantes y su repoblamiento.

\section{Bibliografía}

BERDEGUÉ, Julio; JARA, Esteban; MODREGO, Félix; SANCLEMENTE, Ximena y SCHEJTMAN, Alexander. Ciudades rurales de Chile. [En línea]. RIMISP. 2010. [Fecha de consulta: 05/febrero/
2015]. Disponible en: http://www.rimisp.org/wpcontent/files_mf/13720778491366349339N612010BerdegueJaraModregoSanclementeSchejtmanCiudadesruralesChile.pdf.

CRÓNICA: Reconstrucción rural en tela de juicio. [En línea]. 24 horas. 2013. Disponible en: http:// www.24horas.cl/regiones/maule/cronica-reconstruccion-rural-en-tela-de-juicio-543489.

DELEGACIÓN Presidencial Para la Reconstrucción. Diagnóstico del estado de la reconstrucción tras el terremoto y tsunami del 27 de febrero de 2010. Santiago, Chile, Ministerio del Interior y Seguridad Pública. 2014.

--- Plan de cierre reconstrucción terremoto y tsunami 27F, 2010. [En línea]. Ministerio del Interior y Seguridad Pública. 2014. [Fecha de consulta: 03 marzo 2015]. Disponible en: http://www.interior. gob.cl/media/2015/02/27F_2015.pdf

GOBIERNO de Chile. Plan de financiamiento para la reconstrucción. [En línea]. Gobierno de Chile. 2010. [Fecha de consulta: 04 julio 2012]. Disponible en: http://www.gob.cl/especiales/plan-de-financiamiento-para-la-reconstruccion-y-el-programade-gobierno/.

IASC. Directrices operacionales del IASC sobre la protección de las personas en situaciones de desastres naturales. Proyecto de Brookings -Bern sobre Desplazamiento Interno. 2011.

LETELIER, Francisco y BOYCO, Patricia. Talca posterremoto: una ciudad en disputa. Santiago, Chile, Ediciones SUR. 2011. ISBN 978-956-208-096-5. 
MICHELETTI, Stefano, coord. Informe: el pos-terremoto en los sectores rurales de la comuna de Talca. [En línea]. Surmaule. 2011. [Fecha de consulta: 13 de octubre de 2014]. Disponible en: http:// www.surmaule.cl/wp-content/uploads/2013/07/ INFORME-EL-POS-TERREMOTO-EN-LOSSECTORES-RURALES-DE-LA-COMUNA-DETALCA-ONG-SURMAULE.pdf.

MINISTERIO de Vivienda y Urbanismo. Informe avance de reconstrucción Maule. [En línea]. MINVU. 2013-2014. [Fecha de consulta: 29 de noviembrede 2014]. Disponible en: http://www.minvu.cl/ opensite_20131017161923.aspx.

--- Ordenanza 1401 en respuesta a solicitud de información Ley $\mathrm{N}^{\circ}$ 20.285. 2013

--- Ajustes a la política habitacional: enero 2011. [Santiago], MINVU. 2011.

--- Programa de Reconstrucción de Vivienda: ¿Cómo postular a un subsidio de reconstrucción? [Santiago], MINVU. [2010].

--- Plan de reconstrucción MINVU: Chile unido reconstruye mejor. Santiago, Chile, MINVU. 2010. ISBN 978-956-7674-49-7.

--- Preguntas frecuentes. [En línea]. MINVU. s.f. Disponible en: http://www.minvu.cl/opensite_20100813170929.aspx.

MINISTERIO Secretaría General de la Presidencia. Resumen avance y proyecciones de la reconstrucción del terremoto del 27 febrero 2010. [En línea]. Ministerio Secretaría General de la Presidencia. 2011. [Fecha de consulta: 04 julio 2012].
Disponible en: http://www.minsegpres.gob.cl/ wp-content/uploads/2011/08/110827-ResumenInforme-Reconstrucci\%C3\%B3n.pdf.

MINURVI. Programa Chile Barrio. [En línea]. MINURVI. 2006. [Fecha de consulta: 22 noviembre 2014]. Disponible en: http://www.minurvi.org/documentos/Foro_Adjuntos/Programas_yo_\%20Instrumentos/mnieto\%20-\%205_05_06\%20-ProgInstr.pdf.

MORELLAT0, Chiara. Políticas públicas de reconstrucción y emergencia en sectores rurales. Tesis de grado para optar al título de Cooperación al desarrollo de la Universidad de Padua.

OBSERVATORIO de Ruralidad. Minuta sobre el proceso de reconstrucción en zonas rurales. En: Conversatorio sobre reconstrucción en zonas rurales. Talca, Chile, Observatorio de Ruralidad. 2014.

¿QUÉ es derecho a la vivienda? [En línea]. Derecho a la vivienda I La vivienda es un derecho humano. s.f. [Fecha de consulta: 05 febrero 2015]. Disponible en: http://direitoamoradia. org/?page_id=46\&lang=es

PIGA, José Antonio. Pobladores y vivienda rural: un programa de reconstrucción después del terremoto de 1985. [En línea]. Revista de Geografía Espacios. 1(2): 147-163, 2011. [Fecha de consulta: 5 febrero 2015]. Disponible en: http://www.geoacademia.cl/revista/Piga\%202012.\%20espacios2.pdf

LA RECONSTRUCCIÓN reprobada por los expertos [En línea]. Sentidos Comunes. 2011. [Fecha de consulta: 12 julio 2014]. 
Disponible en: http://www.sentidoscomunes.cl/ la-reconstruccion-reprobada-por-los-expertos/

ROJAS HERNÁNDEZ, Jorge; MORENO ROMERO, Jenny y VALENZUELA FUENTES, Katia. Informe final estudio: Diagnóstico de necesidades no cubiertas de vivienda en las áreas rurales afectadas por el terremoto. [En línea]. Cruz Roja. 2011. [Fecha de consulta: 28 de julio de 2014]. Disponible en: http://www.cruzroja.cl/publicaciones/descarga/ INFORME_CRUZ_ROJA.pdf.

SAN Clemente: Empresas contratistas reciben ultimátum por demora en reconstrucción rural. [En línea]. 24 horas. 2013. Disponible en: http:// www.24horas.cl/regiones/maule/san-clementeempresas-contratistas-reciben-ultimatum-pordemora-en-reconstruccion-rural-551435

SERVIU Región del Maule. Informe de Proyectos Construcción en Nuevos Terrenos (CNT) y Densificación Urbana (DU). 2014.

--- Mapas de localización de proyectos CNT para las comunas de la Región del Maule. 2014

--- Ordenanza 5590 en respuesta a solicitud de información Ley No 20.285. 2013

TAPIA, Ricardo. Algunas reflexiones del impacto de la política habitacional chilena en el medio rural [En línea]. Instituto de la Vivienda - Universidad de Chile. 2006. [Fecha de consulta: 12 octubre 2014]. Disponible en: http://vivienda.uchilefau. cl/2006/12/algunas-reflexiones-del-impacto-dela-politica-habitacional-chilena-en-el-medio-rural/
TERMINOLOGÍA: términos principales relativos a la reducción del riesgo de desastres. [En línea]. Estrategia Internacional Para la Reducción de Desastres. 2014. [Fecha de consulta: 13 octubre 2014]. Disponible en: http://www.eird.org/esp/terminologia-esp.htm.

VALENZUELA, Nicolás. Innovación institucional y conocimiento en tiempos de reconstrucción. En: CARES, Carolina, comp.; IMILAN, Walter, comp. y VERGARA, Paulina, comp. Reconstrucciones sociedad civil: experiencias de reconstrucción en Chile post $27 \mathrm{~F}$ desde la sociedad civil. [Santiago, Chile], Observatorio de la Reconstrucción. 2011. p. 27-34. 